\author{
Володимир Олександрович Котюк, \\ кандидат юридичних наук, професор кафедри \\ теорії права та держави Київського національного \\ університету імені Тараса Шевченка
}

\title{
МОРАЛЬНО-ЕТИЧНА ФІЛОСОФІЯ КОНФУЦІЯ
}

Постановка проблеми. Конфуцій (551-479 рр. до н. е.) народився в повіті Чанпін на сході Китаю в князівстві Лу, яке існувало з XI по ІІІ ст. до н.е. (на території сучасної китайської провінції Шандунь). Його родина належала до стародавнього аристократичного роду, який майже зубожів у той період. Батько Конфуція Шулян Хе управляв повітом цзоу князівська Лу і коли народився Конфуцій, йому було 70 років. Батько Конфуція мав дві дружини, від яких народилося 10 дітей, у т. ч. 9 дівчаток і один хлопчик-інвалід. Його мати була третьою наймолодшою дружиною батька, від якої народився вже Конфуцій, але про неї історія нам залишила мало інформації. Коли майбутньому філософу виповнилося 3 роки, помер його батько, а в 17 років залишився і без матері.

Аналіз останніх досліджень і публікацій. Окремі аспекти морально-етичної філософії досліджувались такими вченими, як Таранов П. С., Андрющенко В. П., Демиденко Г. Г. та ін.

Дійсне ім'я, яке отримав майбутній філософ при народженні було Кун цю. Стараннями його учнів і послідовників це ім'я поступово змінилось почесним прізвищем Кун Фуцзи, яке означало Почесний Учитель Кун. Через багато століть, у XVII ст. місіонери-єзуїти з Свропи приїхали в Китай і позначилися з його етичною філософією або вченням, i зробили китайського мудреця надбанням усієї європейської культури, а його ім'я латинізували - Конфуцій [1, с. 62].

У 17 років він, залишившись без батьків і засобів до життя або існування, змушений був тяжко i багато працювати і одночасно вчитися. Він мав надзвичайно великі природні здібності і обдарування, які дозволили йому при допомозі постійної систематичної праці із дрібного чиновника стати видатним і згодом всесвітньовідомим філософом. 3 цього приводу він говорив про себе: «У п’ятнадцять років я направив усі свої зусилля (помисли) на навчання. У тридцять років я здобував самостійність. У сорок років я позбавився від сумнівів. У п’ятдесят я пізнав волю Неба. У шістдесят років я навчився відрізняти правду від неправди. У сімдесят років почав дотримуватися бажань свого серця» [1, с. 57-58].

Із цих положень можна зробити висновок, що Конфуцій, як і Сократ у Стародавній Греції, учився все життя і прагнув пізнати самого себе і волю Бога.

Основні результати дослідження. Конфуцій заснував свою приватну школу, у якій навчалось 3 тис. учнів, 72 із них - особливо близькі, а 12 - були постійно при ньому. У свою школу він приймав усіх бажаючих вчитися незалежно від соціального статусу молодих людей. Спочатку він брав скромну плату за навчання, а згодом почав жити за рахунок декількох багатих учнів, які надали йому приміщення для його школи. Він, як Піфагор і Сократ, вчив у усній формі і нічого не залишив у письмовій формі. Усе, чому вчив Конфуцій своїх учнів дійшло і стало відомо усім - записи його учнів. За переказами учнів він створив «Книгу пісень» («Шидзин»), для якої відібрав 305 пісень iз більше ніж 3 тисячі народних і ритуальних пісень за період із XI по VII століття до н. е. Крім того, учні створили збірник висловлювань і настанов «Бесіди і висловлювання» («Лунь(юй)), на створення якого було затрачено 80 років, і вперше він з'явився біля 400 р. до н. е.

У своїй школі Конфуцій навчав однаково як чужих, так своїх власних дітей - доброзичливо, вимогливо, з великою любов'ю і повагою. Як в античний, так і сучасний період основний принцип педагогіки гласить: «Максимум вимогливості і максимум поваги до дітей (до учнів і студентів) незалежно від соціального статусу особистості». За переказами, одному з учнів Конфуція, який з великим прагненням бажав засвоїти (осягнути) усі таємниці науки свого Учителя, здалося, що він не все розкриває своїм учням, а головне він повідомляє тільки обраним. I цей учень вирішив, що самому головному Учитель вчить власного сина. Зустрівшись одного разу з цим сином, він його запитав: «Чи є що-небудь особливе, про що ти чув від батька?» Той відповів: «Ні, якось одного 
разу Учитель був один. Я перебігав у цей час у дворі, і він запитав мене: «Ти вже вчив Вірші? Я відповів: «Ще ні». Тоді він сказав: «Якщо ти не будеш вчити Вірші, у тебе не буде нічого, про що розмовляти». Тоді я пішов і почав учити Вірші. Іншим разом Учитель знову був один. Я пробігав у цей час у дворі. Він запитав мене: «Ти вже вчив Правила? Я відповів: «Ще ні». Тоді він сказав: «Якщо ти не будеш вчити Правила, у тебе не буде нічого, на чому можна буде утвердитися». Тоді я пішов і почав Правила. Ось про ці дві речі я і чув від нього».

Разом 3 тим Конфуцій не лише навчав своїх учнів у школі, але й з 30 до 66 років він подорожував по країні, проповідуючи своє вчення. Незадовго до смерті Конфуцій заявив своїм учням, що 40 років, протягом яких він проповідував людям, він не говорив їм правду, що він приховував правду під покровом метафор і інакомовності. Аналогічним чином проповідував Ісус Христос і писав Платон у своїх діалогах для того, щоб більш освічені і грамотні люди самі могли здогадатися, про що іде мова. Тому для того, щоб розуміти практичну філософію або етику, як і діалоги Платона учні повинні бути належним чином підготовлені в сфері освіти і науки. Наприклад, без знання в сфері логіки, математики і державної літературної мови неможливо вивчити ні філософію, ні юриспруденцію. Більше того, Конфуцій щиро зізнався своїм учням перед завершенням земного життя: «Ця правда полягає у тому, що покладати надії можна тільки на дещо і на пустоту, яка $є$ першопочатком усіх речей» $[1$, с. 63$]$.

У 479 р. до н. е. Конфуцій припинив свої заняття, відчуваючи наближення кінця земного життя. У розмовах із своїм учнем Цзи Кунгом він увесь час повертався до стародавніх часів. Він знову і знову скаржився на те, що «не знайшлось ні одного правителя, який захотів би стати його учнем». Під кінець він 3 тугою запитав: «Хто після моєї смерті візьме на себе обов'язок продовжувати моє вчення?» Це були останні його слова. Учні поховали свого Учителя там, де він сам незадовго до своєї смерті вибрав місце для своєї могили: на березі невеликої річки, під покровом благородних кипарисів. У 555 р. до н. е. був виданий імператорський Указ про побудову в почесному місті храму в честь Конфуція і про регулярні жертвоприношення в цих храмах. Спочатку на головному олтарі таких храмів стояли поминальні таблички з іменем Конфуція. Потім таблички були замінені скульптурами. На п’єдесталі пам'ятника Конфуцію в головному корпусі храму і пантеону Конфуція, який займав більше 20 га, існує напис такого змісту: «Самий святий, який обдарований даром передбачення мудрець Конфуцій - місце упокоєння його духу» [1, с. 63-64]. Таким чином, учні і китайський народ оголосили його святим за те, що він був віруючим, гуманістом, дотримувався волі Бога і його Закону, відправляв релігійні культи. У своїх висловлюваннях він говорив: «Найвища мета життя людини полягає у тому, щоб відшукати і реалізувати в житті волю Бога, Закон його, тобто проявляти істинну, моральну сутність нашого «я».

Воля Бога - це те, що ми називаємо Законом нашого життя. Виконання Закону нашого життя і $€$ те, що ми називаємо моральним, істинним життям. «... Той Закон, від якого можна було б ухилитися, вже не $\epsilon$ Закон...» [2, с. 13-14].

У 136 р. до н. е. імператор У-ді проголосив конфуціанство офіційною державною доктриною, а сам Конфуцій був обожнений. Він $є$ творцем етико-політичного вчення, яке протягом більше двох тисяч років зробило величезний вплив на розвиток духовного і політичного життя Китаю. Конфуціанство виховувало своїх послідовників у дусі поваги до існуючих порядків, за Законом «Жень», який був вказаний Небом, Людина зобов’язана була виконувати і дотримуватись цього Закону і норми етикету і прагнути до морального вдосконалення: виконувати обряди, поважати предків, зберігати традиційний порядок, свято дотримуватися принципів соціальної ієрархії. Конфуцій створив концепцію ідеального або благородного мужа, яким стають не за походженням, а шляхом досягнення високих моральних якостей: гуманності, відданості, вірності, щирості, справедливості, поваги по відношенню до старших [3, с. 44].

Концепція ідеального або благородного чоловіка, за переказами учнів і послідовників, увійшла в Збірник «Лунь-юй» («Бесіди і судження або висловлювання»), який відразу ж після смерті Конфуція став каноном його вчення. Ця концепція благородного або шляхетного чоловіка викладена в таких основних положеннях, які виражають основні морально-етичні властивості і якості такої особистості:

1) благородний або шляхетний чоловік турбується або думає про дев'ять справ: а) про те, щоб ясно бачити; б) про те, щоб чітко слухати (чути); в) про те, щоб його обличчя було привітним; г) про те, щоб його вчинки були високоморальними; г) про те, щоб його мова була щирою; 
д) про те, щоб його діяння були обережними; е) про необхідність пам'ятати про наслідки свого гніву; є) про необхідність пам'ятати про справедливість; ж) коли є можливість отримати користь [1, с. 58];

2) благородний чоловік думає про праведний шлях і не думає про їжу або харчування. Він може працювати в полі - i бути голодним. Він може присвятити себе навчанню - i приймати щедрі нагороди. Але благородний чоловік турбується про праведний шлях і не турбується про бідність;

3) благородний чоловік не прагне їсти до ситості і жити заможно. Він поспішає у справах, але повільний у розмовах. Спілкуючись із добродійними людьми, він виправляє або вдосконалює себе;

4) благородний чоловік знає про свої переваги, але уникає суперництва. Він живе у згоді з усіма, але ні з ким не вступає у зговір;

5) благородний чоловік ні від кого не очікує обману, але коли його обмовляють, він перший помічає це;

6) благородний чоловік допомагає людям бачити те, що $є$ в них гарне і добре, i не вчить людей бачити, те, що є в них погане і дурне. А безкультурна людина вчиняє навпаки;

7) благородний чоловік найбільш за все поважає обов'язок. Благородний чоловік, який наділений відвагою, але не знає обов'язку, може почати займатися грабежем;

8) благородний чоловік з гідністю очікує повеління Неба, а низький чоловік у суєті суєт підстерігає удачу;

9) благородний чоловік знає тільки обов'язок, а низький чоловік тільки користь;

10) благородні люди живуть у згоді з іншими людьми, але не йдуть за іншими людьми, а низькі ідуть за іншими людьми, але не живуть 3 ними у згоді;

11) благородний чоловік душевно спокійний або безтурботний, а низький завжди заклопотаний;

12) благородний чоловік звинувачує сам себе (тобто при невдачах і помилках шукає провину в собі, а не в інших), а маленький звинувачує інших;

13) благородний чоловік стійко переносить невдачі і лиха, а низький чоловік у біді і в нещасті розпускається;

14) благородний чоловік, який прив'язаний до домашнього комфорту, не гідний називатися таким;

$15)$ істинно гуманний чоловік досягає усього власними зусиллями;

16) кожен може стати благородним чоловіком. Необхідно тільки вирішити ним стати;

17) не пізнавши долі, неможливо стати благородним чоловіком. Не пізнавши належного, неможливо здобути опору в житті. Не навчившись розуміти істинний зміст слів, неможливо знати людей;

18) оцінюючи світські справи, благородний чоловік нічого не відкидає і не схвалює, а все вимірює справедливістю;

19) перед чоловіком до розуму - три шляхи: шлях міркування - це самий благородний; шлях наслідування - це самий легкий; шлях особистого досвіду - самий тяжкий;

20) поряд із благородним чоловіком допускають три помилки: розмовляти з ним, коли слова не доходять до нього - це необхідність; не говорити, коли слова до нього дійшли б - це потаємність; і говорити, не спостерігаючи за виразом обличчя - це сліпота [3, с. 44-50].

Існують і інші властивості та якості благородного чоловіка. Наприклад, аналізуючи філософію Конфуція, П. С. Таранов у своїх творах пише: «...Правитель, який не навчає підданого, не може бути прямим. Благородний чоловік (муж), який не наставляє товариша, не може бути добродійним. Чесний чоловік, який отримав урок, стане великим філософом (мудрим). I ніхто із тих, хто любить Вчителя, не піде наперекір належному» [1, с. 65]. Ці положення Конфуцій висловив своєму новому учневі Цзи-Лу, який був майже ровесник Учителю, здоровий, запальний і наділений надзвичайно великим честолюбством, що приїхав із якогось глухого села в Цюйфу на пошуки вдачі і здивував столичних мислителів своїми грубими манерами, тобто був невихований і неосвічений, знав тільки свій гострий меч і своїм мистецтвом володіння мечем вихвалявся, переслідував тільки користь тощо. Після полеміки з Конфуцієм, якщо вірити переказам, Цзи-Лу зрозумів, що знайшов свого вчителя, і з того часу служив Конфуцію з такою ж палкістю, з якою спочатку прагнув доказати свою перевагу [1, с. 65].

На думку Конфуція, мораль благородного чоловіка подібна до вітру, а мораль простої людини подібна до трави. Трава нахиляється туди, куди дме вітер. Один сановник держави Лу-Цзи-Канцзи якось запитав у Конфуція про управління державою: «Як Ви дивитесь на вбивство людей, які позбавлені принципів, у ім'я наближення до цих принципів?». Конфуцій (Кун-цзи) відповів: 
«Для чого, управляючи державою, вбивати людей? Якщо ви будете прагнути до Добра, то і народ буде добрим. Моральні благородного мужа подібна до вітру. Мораль простої людини подібна до трави. Трава хилиться туди, куди дме вітер» [1, с. 65].

Правителі держави і керівники підприємств і установ завжди були еталоном або зразком для своїх підлеглих. Розумні і мудрі правителі добре знали загальні принципи моралі і управління державою і будь-яким виробничим, трудовим чи навчальним закладом. Особистий приклад керівника (в трудовій діяльності і у повсякденному житті і у поведінці) був зразком для аналогічної поведінки і діяльності членів різних виробничих колективів і навчальних закладів. Про це розумів ще Конфуцій в античні часи. На запитання одного із перших своїх учнів Цзи-Лу: «Як досягти підкорення людей, не змушуючи їх жити в страху?». Конфуцій відповів: «Своїм особистим прикладом спонукай людей працювати». Цзи-Лу трохи збентежений: «Адже відповідь, здається, прихована в ньому самому! Але він усе ще хотів поступитися і запитав: «Припустимо, що я досягну цього. А що потім? - «Не дозволяй собі розслаблюватися» - відповів Конфуцій учневі, який розгублено мовчав [1, с. 206-207]. Тому правителі держави і керівники підприємств і установ зобов'язані турбуватися про навчання і виховання всіх громадян у дусі поваги до права, до закону, до правопорядку, які виражають і захищають матеріальні і духовні цінності, права і свободи всіх громадян і юридичних осіб.

Крім того, на питання царя держави Ці Цзин Чуна, як управляти державою? - Конфуцій відповів: «Правитель повинен бути правителем, державний службовець (сановник) - державним службовцем, батько - батьком, син - сином». Цю відповідь можна розуміти по-різному, але з позиції морально-етичної філософії, це означає, що кожна особа повинна бути дійсно на своєму місці і добросовісно та доброякісно виконувати свої державні повноваження, професійні і громадянські обов'язки.

На думку Конфуція: «Саме головне в житті - це знати його сенс, мету, до якої ми повинні прагнути, істинне наше призначення і потім вже приймати рішення, який обрати собі шлях».

I для самої знатної людини, яка стоїть наверху, і для самої простої людини, яка стоїть внизу, є тільки один обов'язок у житті: виправляти і покращувати самого себе. У цьому основа життя, в цьому - джерело всезагального Блага. Якщо людина почує вранці, в чому полягає сенс життя, то без жалю може помирати в той же день» [2]. Таким чином Конфуцій вважав, що кожна людина, незалежно від іiі соціального статусу, зобов'язана самоудосконалювати себе, бути добродійною і мудрою.

Про добродійність і мудрість він говорив: «Мудрість життя в тому, щоб його усвідомити в собі і підняти світле начало розуміння, яке ми отримали від Бога. Мудрість життя в тому, щоб оновлювати людей, навчати їх тому, що найвище їх благо - в розкритті цього Божественного начала, у все більшому і більшому вдосконаленні. ... Із хати виходять тільки через двері добродійності. Добродійність ніколи не залишається самотньою, нею завжди захоплюються сусіди» Добродійність недалеко від нас. Варто тільки побажати бути добродійними, і вона вже тут - i біля нас, і в самих нас» [2].

Велику увагу приділив Конфуцій гуманізму або людинолюбству. На його думку: «Любов це те, в чому проявляється наша божественна сутність. Любов - це початок і кінець нашого існування. Без любові немає життя. Тому-то любов $є$ те, перед чим схиляється мудра людина.

... Чи є таке слово, яке можна було б поставити в основу всіх вчинків людей?.. ... С таке слово, і це слово «шу», яке означає те, щоб не робити іншим того, чого не бажаєш собі ... Усі люди народжені для того, щоб бути добрими. Якщо людина не добра, то це потворність» [2].

Висновки. На думку сучасних вітчизняних філософів, це $\epsilon$ золоте правило моралі. На питання: «Що є «Жень»? Конфуцій відповів: «Не роби людині того, чого не бажаєш собі. I тоді зникне ненависть у державі, зникне ненависть у сім'ї». Аналогічне правило існувало і в Індії: стародавньо-індійські джерела передають розповідь про нетерпеливого і надзвичайно допитливого молодого чоловіка, який ходив до різних високоосвічених людей і просив їх викласти зміст священних книг настільки коротко, щоб цю мудрість можна було б зрозуміти, стоячи на одній нозі. На кінець він прийшов 3 цим проханням до знаменитого Вчителя Законів Хітелу. Той посміхнувся і відповів: «Не роби нікому того, чого ти не хочеш, щоб було зроблено тобі».

Конфуцій, як і багато інших філософів античного світу, вважали, що для виконання будьякої роботи або різних видів діяльності необхідна загальна і спеціальна підготовка. Він говорив: «У будь-якій справі успіх залежить від ступеня готовності до справи: без підготовки до справи мож- 
на наперед передбачити невдачу... За несправедливість платіть справедливістю, за добро - добро. Працюй над очищенням твоїх думок. Якщо у тебе не буде дурних думок. Не буде і дурних вчинків. На думку Будди, корінь гріха знаходиться в мисленні, тому потрібно навчитися добре і правильно мислити. Античні філософи вважали, що людина повинна навчитися не лише правильно мислити, але й правильно і гарно розмовляти, а потім правильно діяти.

«Будь завжди уважний до того, що робиш, і нічого не вважай негідним уваги. Володіти собою настільки, щоб поважати інших, як самого себе, і вчиняти з іншими так, як ми бажаємо, щоб з нами вчиняли» - ось правильний шлях життя, істинна поведінка [2].

«Про мудру і духовну людину він говорив: «Життя мудрого, морального чоловіка - це реалізація на землі Закону життя, волі Бога... Мудрий чоловік усе необхідне йому шукає в собі ж, а темний чоловік - в інших. Освічений чоловік завжди намагається допомогти вияву найкращих властивостей у інших людей, темний чоловік вчиняє навпаки».

Конфуцій також писав і про помилки людей, які схильні помилятися. На його думку: «Зло помилки не в тому, що вона буває, а в тому, що люди, які зробили помилку, не намагаються виправити ііі.

Правитель однієї провінції скаржився на те, що у нього в провінції багато злодіїв, і просив поради, як їх позбутися. Конфуцій сказав: «Якби Ви «загнуздали» свою жадібність, то у Вас не було б і злодіїв». Люди не стали би вчиняти крадіжку, навіть якби Ви і запропонували нагороду за крадіжку».

Таким чином, Конфуцій проповідував високоморальні і правильні принципи і закони життя людей, бути мудрими, гуманними, поважати і любити інших людей і самих себе, вести правомірний спосіб життя тощо.

\section{Список використаних джерел}

1. Таранов П. С. 500 шагов к мудрости : в 2 Т. Донецьк. Сталкер. 1996. Т. 1. С. 203-204. Також Таранов П. С. 120 философов. Жизнь. Судьба. Учение. Мысли : в 2-х т. Сімферополь, «Реноме», 2002. Т. 1.

2. История политических и правових учений : хрестоматія. Составитель и общ. ред. Г. Г. Демиденко. Харьков, 1999.

3. Мудрость тысячелетий : энциклопедия. М. : Олма-Пресс. 2005. Автор-составитель В. Балязин.

DOI: 10.33.66.3/2524-017X-2019-10-153-157

УДК 340.132

Катерина Геннадї̈вна Кравчук, аспірант юридичного факультетуКиївського національного університетуімені Тараса Шевченка

\section{ПРАВОВИЙ СТАТУС СУДІВ ЯК СУБ'СКТІВ ПРАВОТВОРЧОСТІ: ПРАВОВІ АСПЕКТИ МОНІТОРИНГУ}

Постановка проблеми. Аналіз правового статусу судів України, його змісту та характеру реалізації в межах судової діяльності має важливе значення для пізнання та комплексної характеристики їх ролі у правотворчій діяльності, оскільки саме суди є єдиними органами здійснення правосуддя в державі, діяльність яких націлена насамперед на захист прав, свобод та законних інтересів суб'єктів права. Разом з тим дослідження правового статусу судів України крізь призму його правового моніторингу надасть змогу визначити їх місце та роль в системі суб'єктів правотворчості та механізмі правотворчої діяльності, що має вагоме теоретичне та практичне значення для удосконалення правотворчої діяльності, підвищення рівня процесуально-суб'єктних засад ії здійснення, а також уточнення їх правотворчої компетенції в процесі здійснення правосуддя.

Особливої актуальності зазначені питання набувають у світлі тих реформаційних та інтеграційних процесів, у полі яких на сьогодні перебувають майже всі сфери соціальної та державно-право- 